7-31-2019

\title{
Introduction e-learning in educational sector case study Senior High School in DKI Jakarta
}

Fikri Anza

Faculty of Administration Science, Universitas Indonesia, fikriakbarsyah@ui.ac.id

Achmad Luthfi

Faculty of Administration Science, Universitas Indonesia

See next page for additional authors

Follow this and additional works at: https://scholarhub.ui.ac.id/ajce

Part of the Social and Behavioral Sciences Commons

\section{Recommended Citation}

Anza, Fikri; Luthfi, Achmad; and Saragih, Arfah (2019). Introduction e-learning in educational sector case study Senior High School in DKI Jakarta. ASEAN Journal of Community Engagement, 3(1).

Available at: https://doi.org/10.7454/ajce.v3i1.149

Creative Commons License

(c) (i) ()

This work is licensed under a Creative Commons Attribution-Share Alike 4.0 License.

This Research Article is brought to you for free and open access by the Universitas Indonesia at ASEAN Journal of Community Engagement. It has been accepted for inclusion in ASEAN Journal of Community Engagement. 


\title{
Introduction of e-learning in the educational sector, Case study: Senior High Schools in DKI Jakarta
}

\author{
Fikri Anza ${ }^{a^{*}}$, Achmad Lutfia, Arfah Saragih ${ }^{\mathrm{a}}$ \\ aFaculty of Administrative Science, Universitas Indonesia
}

\begin{abstract}
Information Technology Needs in the current community are very high and mighty dynamics. This need can be seen from the many aspects of community life that cannot be separated from the dependence on the use of ICTs. This dependency also occurs in the education environment, especially the context of senior high school level education in DKI Jakarta. If schools can implement this new type of learning optimally, it'll be possible there are no longer needed a separate class of national level test in Indonesia, question bank and teaching material can be shared between schools in Indonesia, and learning can be done in wherever, whenever, and whoever wants to study. This research activity was carried out derived from the results of direct observations, which had problems in the aspects of HR (teachers, students, and technical staffs), Technology Infrastructure, and leadership. This research was conducted using descriptive qualitative methods. The results showed that there were still many teachers who were not aware of the importance of Learning Management System (LMS) so that the participation of teachers and students even used traditional methods. The student's commitment has what commitment their teacher will give if the teachers have not been committed to using LMS optimally, so will their students. LMS technical staffs themselves also face similar problems, where the direction of professional crews implementing LMS depends on the course of the leader.
\end{abstract}

Keywords: e-learning; high school; learning management system; knowledge management; moodle; DKI Jakarta; Indonesia

\section{Introduction}

IT-Based education, or commonly called E-Learning, is a form of education that utilizes IT in the way of its teaching. This form of teaching already defined early time in the 90s (in 1988 to be precise) as a based foundation for E-Learning concept. E-learning teaching method, using technology to support learning activities may also occur between teachers and students who are separated between space and time so that the form of teaching can be in the way of distance teaching (Keegan, 1988). This form of teaching was also confirmed by Minister of Education and Culture Regulation No. 109/2013 which states that teaching models conducted remotely through various communication media can be permitted to be implemented in Indonesia (Kemendikbud, 2013). This regulation also endorsed for Computer Based Test in Final Evaluation Test in Education by Minister of 
Education and Culture Regulation No. 114/2014 that became a standard based for the usage of E-Learning for National Computer Based Test (Kemendikbud, 2014). Therefore, the role of IT in supporting this form of IT-Based learning that can be done anywhere, anytime, and with anyone is necessary to be immediately implemented in schools both elementary and tertiary level.

Looking at the importance of the role of IT in education, it was seen that high school education is the level of knowledge which is the main turning point for students' lives (Najmul Islam, 2011; Loh, C., Wong, D., Quazi, A., Russel, P., 2016). Seeing from the enthusiasm of the Ministry of Education and Culture itself that in the last few years began holding Computer-based University entrance exams, as well as the number of universities that entered the ranking of the best universities in Indonesia alone have included an ITBased teaching curriculum in each Their lecture (Susanti, 2015). However, things like this are still considered as a problem that will be faced by their School alumni in the future, not a problem for the School.

That perspective is wrong, though, because the preparation of students in higher education is also the responsibility of high schools in preparing their graduates. Especially with the use of E-Learning that is good in the school environment, schools get many benefits directly or indirectly. Starting from the formation of a knowledge repository for teachers and students, teaching files that can be used continuously, the collection of question banks between generations, and preparing students to adapt in the form of ELearning based teaching for them in the future. Even though the school itself has implemented the LMS for its schools, this also cannot be separated from the problems that may be faced (Al-Adwan \& Smedley, 2013).

This problem can be seen from the object of Community Service to be carried out, namely the State Senior High School 34 South Jakarta (SMAN 34). SMAN 34 has been trying to implement an IT-Based education system in its teaching. However, after seeing at a glance and discussing with the teachers, managers, and alumni of SMAN 34, the fact was that they still did not use E-Learning optimally. If they can implement this new type of learning model in their schools optimally, it's not impossible if every single school in Indonesia can use it right away. So, there are no longer needed a separate of the national level test in Indonesia, question bank and teaching material can be shared between schools in Indonesia, and learning can be done in wherever, whenever, and whoever wants to study or as a ubiquitous approach (Clover, 2017). 


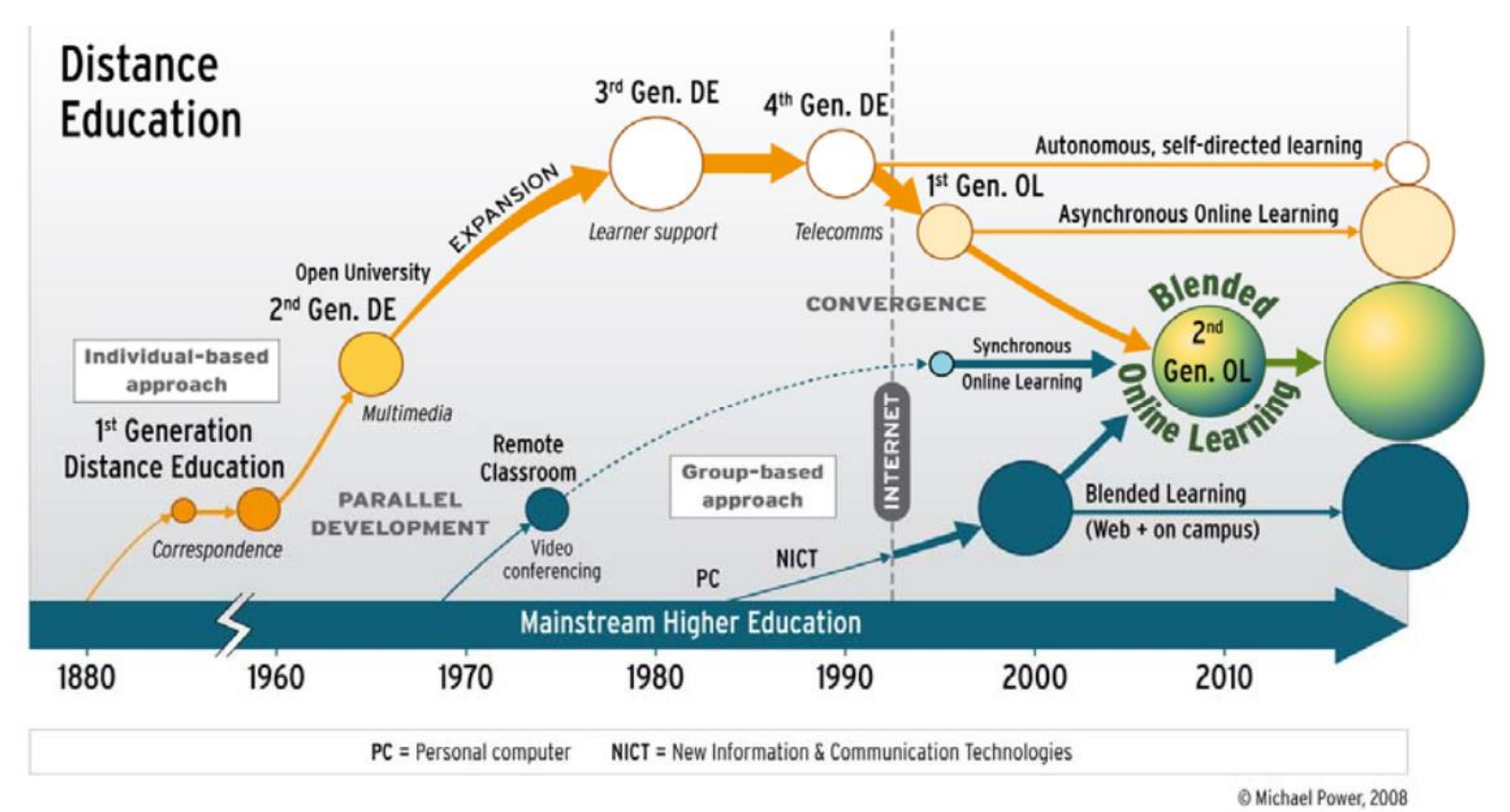

Fg. 1 History of the Use of E-Learning in Education

Source: Distance Education (Power, 2008)

In 2008, Power created a based concept of E-Learning (Distance Education) style developed over time. From the $1^{\text {st }}$ Generation Distance Education, they used a traditional approach for responding to their individual-based plan. The $2^{\text {nd }}$ Generation Distance Education was the first time that multimedia is used in helping the student to understand the subject clearly. The $3^{\text {rd }}$ Generation Distance Education was the first time they use a learner (student) perspective to give feedback or respond directly (Student-Centered Learning introduced). The $4^{\text {th }}$ Generation Distance Education was the first-time ELearning can be used using Telecomm, such as telephone, video, etc. After that, in the 1990s, the internet introduced in the Learning environment; and Distance Education concept back to the first one but using ICT as support. The $1^{\text {st }}$ Old Generation Distance Education using the asynchronous method, a student using self-directed learning in online media. The $2^{\text {nd }}$ Old Generation Distance Education, E-Learning can be used in the synchronous approach, and students can learn using an offline press or online media (Blended Online Learning) (Power, 2008). Today, some studies said Distance Education already entered in $5^{\text {th }}$ Generation Distance Education, which is Distance Education that using ubiquitous concept whereas any student can learn anytime and anywhere (Salmon, 2013). 
After three years of LMS implementation at SMAN 34 Jakarta School, it turned out that the use of the LMS was only a place to practice before facing the Computer-based test. LMS implementation was worsened by its use only in 12th-grade students who were going to graduate, while for 10th and 11th-grade students were not given a form of Computer-based teaching at all until the end of their study year at SMAN 34 Jakarta.

The human resources involved in using the LMS also have problems in the operation of the LMS. Many of them do not know how to use LMS correctly, even though the LMS is beneficial for both the teacher and students; as a small example is a place for centralized information sharing (sharing teaching material slides and task collection). The perception between the teacher and the LMS manager itself is still not aligned, so there are still technical differences of opinion regarding the use of the Quiz Online feature provided by LMS, which causes the added value of the LMS to be lost.

In academic perspective, there are some fundamental problems that occurred, such as 1) school is not aware in E-Learning concept that makes they do not create a learning method how to utilize LMS in their school; 2) they do not design any E-Learning approach in their learning method (still using traditional learning method), even if they knew regulation for using E-Learning already established; 3) point number 2 can be seen from the academic curriculum that was still using traditional method until now; 4) they do not give any training related to E-Learning method, even they still had a problem in IT-related literacy; 5) they do not provide any budget for developing E-Learning method, just using budget as possible as they need minimally; 6) Gap in IT savviness in teachers and academic staffs; 7) and list can be going any further. Here we can see; the school commitment to using E-Learning need to look further. This problem can be seen in the leadership that the school uses.

Priority problems identified from this activity are socialization of the main benefits of applying LMS, mapping the current state of LMS usage, vision of the use of LMS, conducting gap analysis of existing conditions and expected conditions in the future, providing training in accordance with the needs needed, conduct monitoring and evaluation for one month after the training is conducted. Here we can see; the digital governance is the primary concern for E-Learning can be a success.

For the solution itself, the answer will be tried out from the needs analysis (the results of the gap analysis); and will be adapted to some of the best practices in the E-Learning and Moodle handbooks, completion of internet forums and Moodle forums, and technical 
advice assistance from the University's professional team on E-Learning. Further support in literature study needs to look up, such as the concept of E-Learning, Management Information System, and Leadership.

Mainly this research's theories based on journals, books, and reports using a theme from E-Learning, Information System, Knowledge Management, Leadership in Digital Era, and IT Governance.

\subsection{E-Learning}

E-Learning is needed for Education in Indonesia today, because the development of technology itself causes the event of almost all aspects of life to occur, which construction makes things easier. It can be seen from the development of the topic of E-Learning itself in the world, which every year is proliferating (Stoker, 2016). Asia is a region that has a very rapid development, but countries that drive this development mainly are the countries of India, China, and Australia. Seeing regarding the size of the region and the population, Indonesia should have a significant contribution to the development of ELearning activities, but the facts inform others.

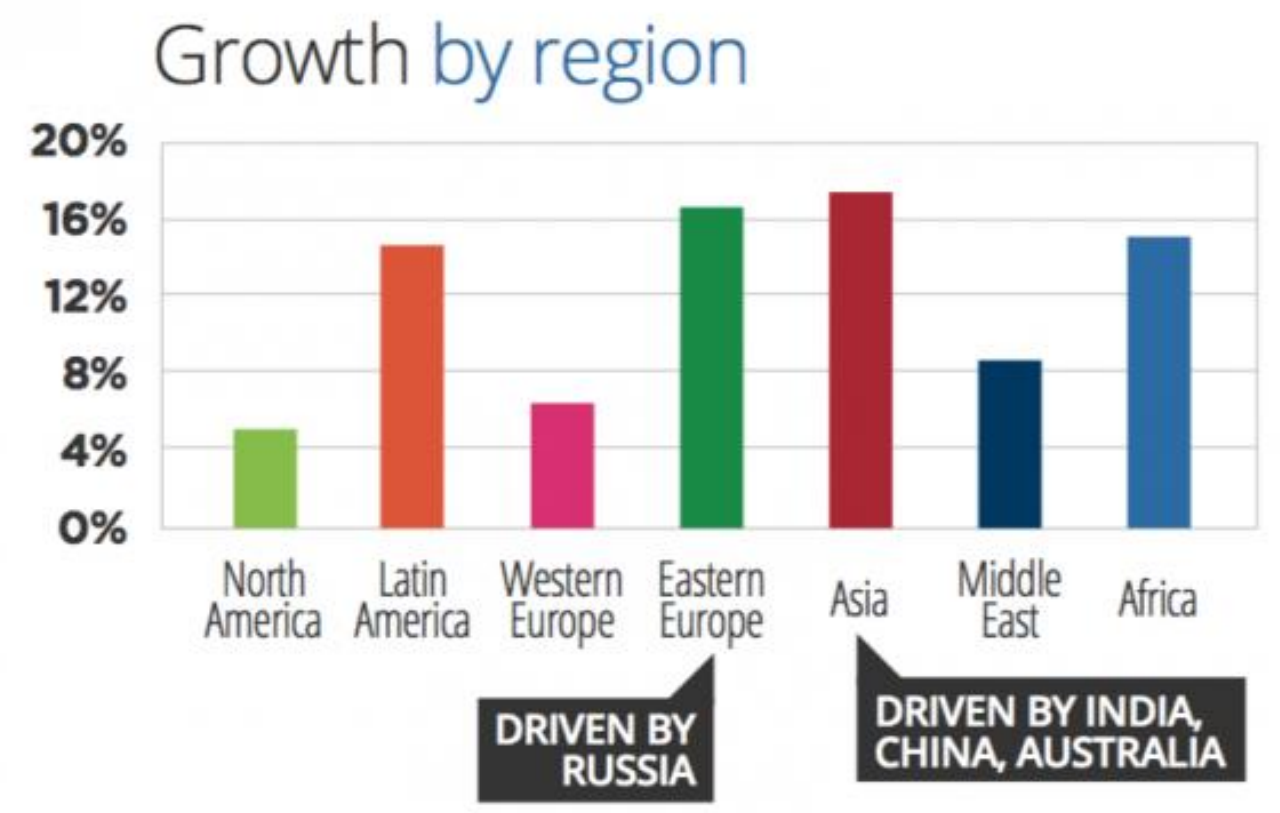

Fg. 2 Global E-Learning Growth 2016

Source: E-Learning Growth (Stoker, 2016) 
From Figure 3, E-Learning was made to be one of the pilot mapping projects regarding creating a national knowledge repository database that is currently not running well. Seeing from several previous studies regarding the development of Education from Paulsen (Paulsen, 1998), about Online Education: Pedagogical, Administrative, and Technological Opportunities and Limitations.

In this study, it can be seen that, in making IT-Based teaching, the teacher's criteria as a role that has a function in determining methods, techniques, and learning tools are considered essential (Aparicio, Bacao, \& Oliveira, 2016). From an outside point of view, the selection of the administrative side regarding determining the learning group, the subject of learning, the scale of knowledge, the location of education, communication, scheduling, and the media can be used too. All of these already included in the modern LMS system, like moodle (Moodle, 2017).

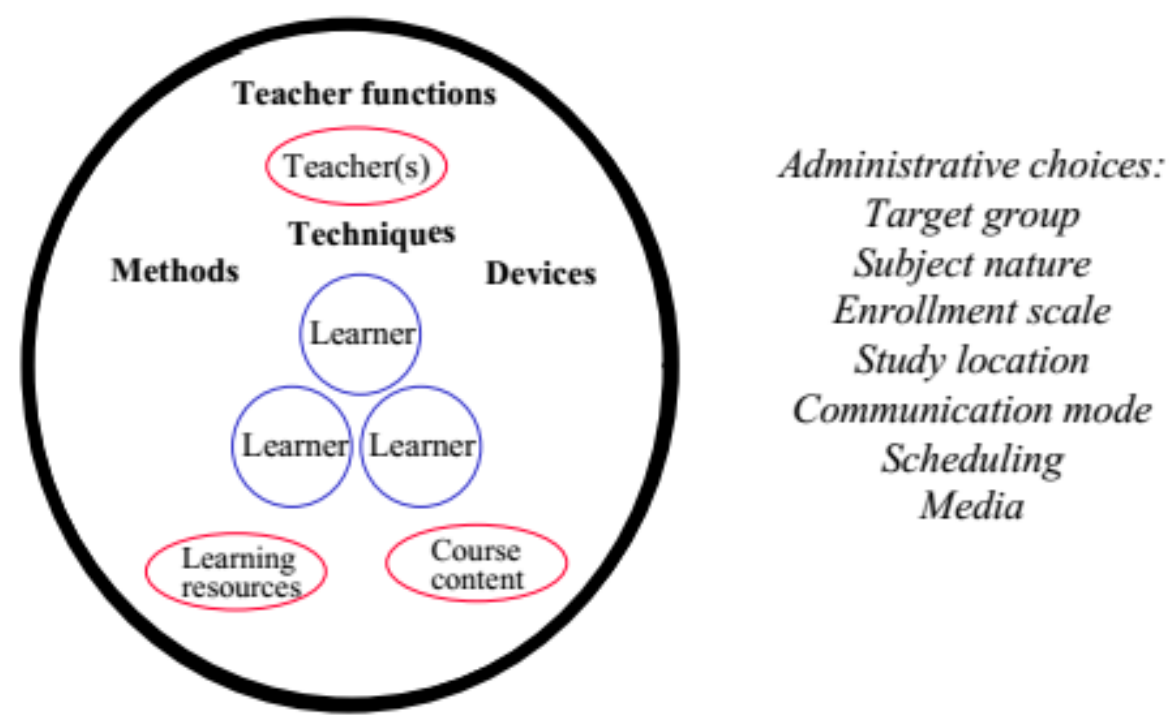

Fg. 3 The Concept of Theoretical Framework in E-Learning Source: E-Learning Framework (Paulsen, 1998)

In another study, from Michael Power (Power, 2008), about The Emergence of a Blended Online Learning Environment, which said that the concept of Blended Online Learning has an optimal value of better use than only done in full online. In this case, the researcher tried to assess the results of the teaching in the form of half-class, half LMS; and provided some excellent supporting media, starting from the emergence of webinars, teaching audio-videos, teaching presentation slides, and conducting online discussions or asynchronous online chat. 


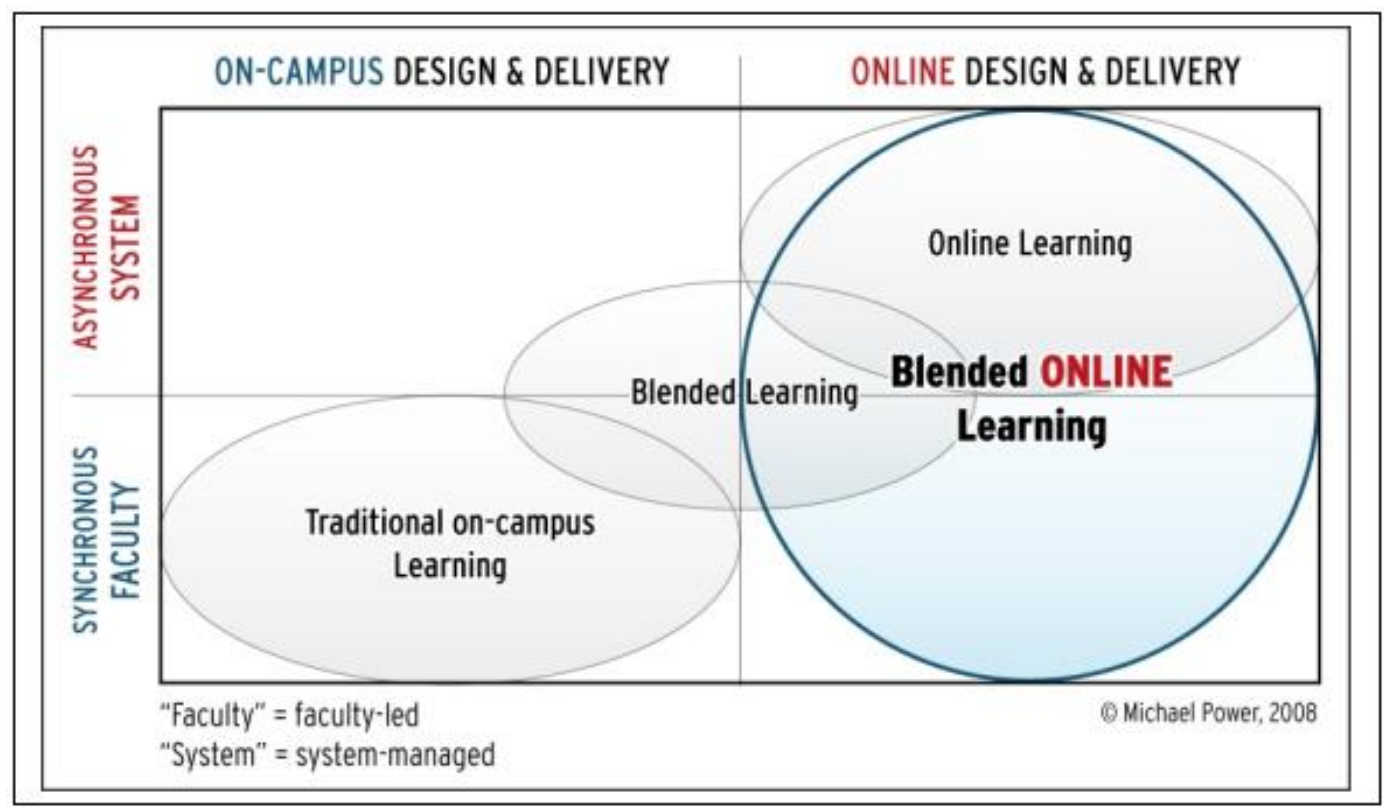

Fg. 4 Mapping Blended Online Learning

Source: Blended Online Learning (Power, 2008)

So, from this literature about E-Learning, we can know that Human, Information System, and Education System need the integrity to make E-Learning success. For that main concept, we know that procedure, technique, method, learning content; had a main role in making E-Learning success too, and that embedded in E-Learning governance (Clark, 2016).

In E-Learning governance itself, Salmon said that E-Learning has a maturity level that educational institutions want to achieve, categorize by interactivity level (Salmon, 2013). It can be seen from the figure below. From this model, we can see what an educational institution must do, to achieve their vision about E-Learning that they use. 


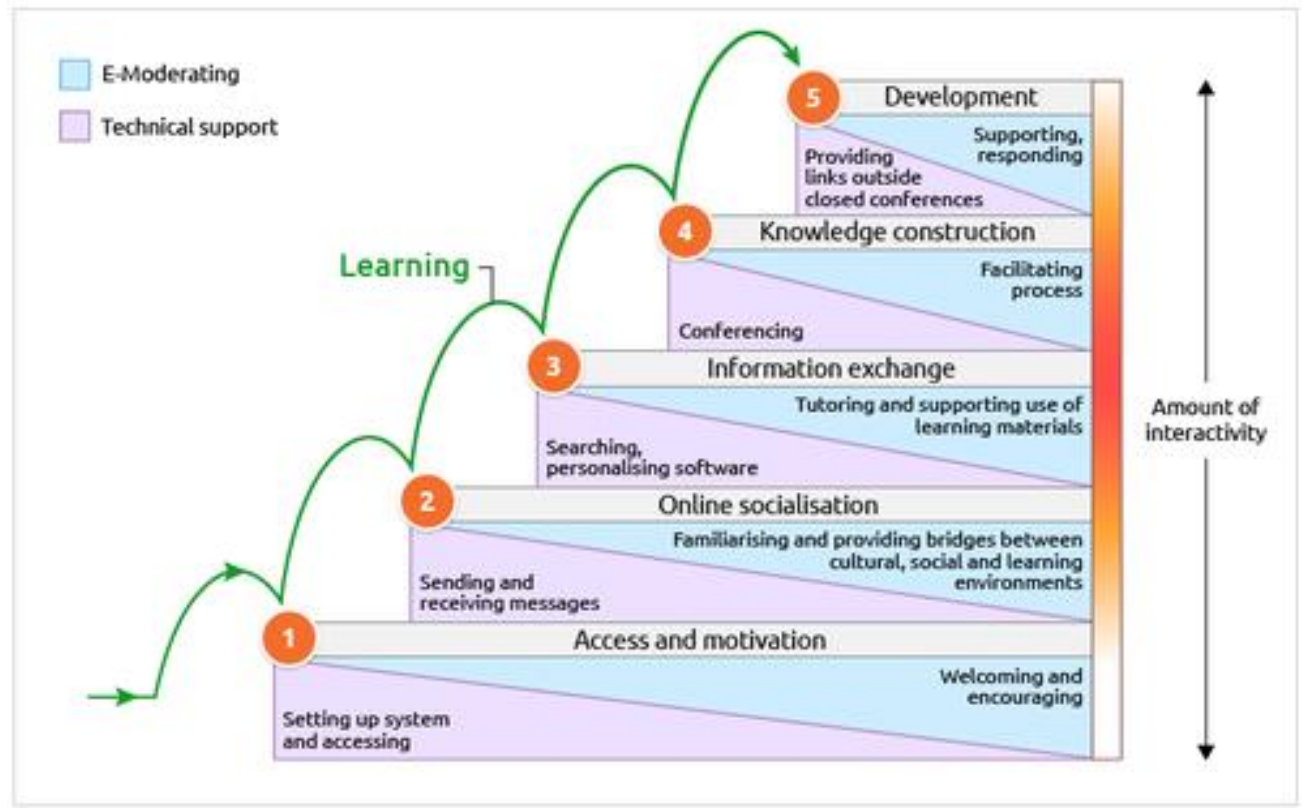

Fg. 5 E-Learning 5 Stage Model

Source: 5 Stage Model (Salmon, 2013)

Beside using 5 Stage Model from Salmon, we can use references from past studies for measuring the E-Learning System Success Model. Regarding to that, in implementing a good E-Learning, we must pay close attention to technical system quality, educational system quality, content and information quality, service quality, user satisfaction, intention to use, user loyalty to system, benefits of using system and goals achievement (Sun, Tsai, Finger, \& Chen, 2008; Hassanzadeh et al., 2012). Though in this activity, we don't do measurement but identify the problem and give a recommendation and improve awareness regarding E-Learning to SMAN 34 Jakarta.

\subsection{Management Information System}

Management Information System is a combination of the words System, Information, and Management. Using a discussion from Gordon B. Davis, in his book "Management Information Systems," the definition of a system is a series of elements that unite and work together to achieve a goal. Next, are David and Olson, explaining the meaning of information is data that has been processed into a form that means for recipients and has value in making actions or decisions. While the understanding of management, according to Koontz in 1972, is the art of solving problems by utilizing human resources in a formal organization. From this understanding, the Management Information System (MIS) can 
be simplified into a system consisting of people, machines, procedures, databases, and data models. MIS collects and processes data from the internal and external environment of the organization in helping managers in the decision-making process (Davis, 2006). And that concept until now still held to define MIS.

A management information system has different tasks and functions and will have different levels of use. This difference in usage level was divided into four types of levels: 1) Transaction Processing; 2) Operation Control; 3) Management Control; 4) Strategic Planning. This difference in levels will lead to different levels of decision making. Complete details can be seen from the figure below. This figure can represent how an organization build an institutional characteristic in staffing and give task-responsibility.

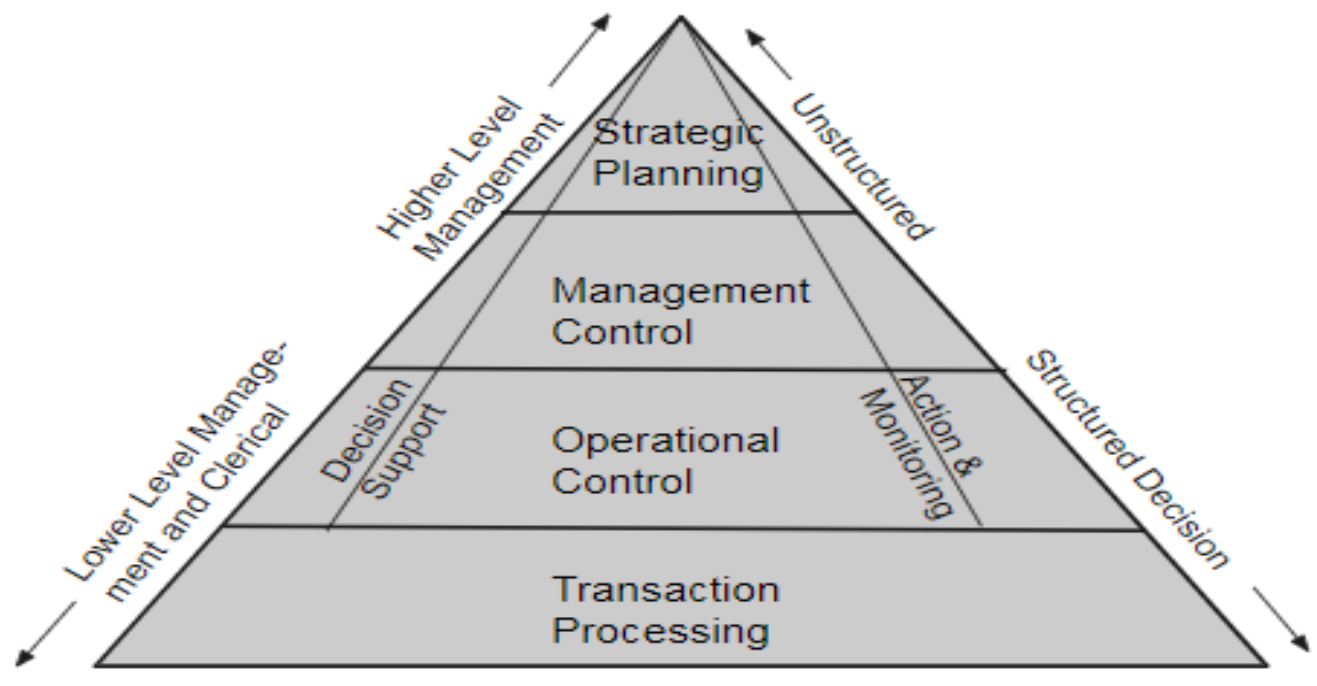

Fg. 6 Management Information System Pyramid Source: Hierarchy MIS (Davis, 2006)

In general, so that the Management Information System runs well, the main components that exist in the concept of Management Information Systems must be aligned with good Digital Governance, namely: 1) Policy to protect the system, the user who use system, and the sustainability of system; 2) Governance which complied to good standard governance in using system; 3) and Information Communication and Technology that support the business of the organization (Nuechterlein, 2013). Besides that, in the digital governance aspect, we need to look again about a) Procedure; b) Human Resource; c) Data Center (Ordonez, 2018). 


\subsection{Leadership}

Leadership was how to lead, how to direct, how to manage, and how to utilize every resource that the organization has. A good leader can influence the organization very well; he/she can accept any opinions they subject have and implemented those opinions for the good of the organization. In practical, good leadership need a good policy that can support he/she visions, and they need good people that can work together to fulfill those visions (Maxwell, 2013).

To make a better move, they need strategic and planning how those vision can be fulfilled. It can be said how to organize your human resources, infrastructure, governance, and organization needs accurately (Dunleavy, 2006). In addition, the leader's commitment will be the critical success factor in any mission organization want to accomplish. This commitment can be a policy, monetary support, an annual work plan, a masterplan, assigning tasks from organization structure (Goodwin, 2018).

\subsection{Research Indicator}

This research mainly using Salmon's theories (Salmon, 2013) to define how mature ELearning running in institution or organization using E-Tivities's Concept, Component of Management Information System from Davis (Davis, 2006), and Governance in Digital Era from Goodwin (Goodwin, 2018), and Leadership from Dunleavy (Dunleavy, 2006).

Table 1. Research Indicator

\begin{tabular}{llll}
\hline Dimension & Aspect & Indicator & Sub-Indicator \\
\hline Leadership & Policy & Governance & E-Learning Team \\
& & & IT Masterplan \\
& & IT Budgeting \\
\cline { 3 - 4 } & ICT & Innovation \\
& & Data Center \\
\hline E-Learning & Governance & Institutional & Integration \\
& & & E-Learning Team \\
& & Strategic Planning & IT Masterplan \\
\hline
\end{tabular}




\begin{tabular}{|c|c|c|c|}
\hline \multirow[t]{9}{*}{ Dimension } & Aspect & Indicator & Sub-Indicator \\
\hline & & & IT Budgeting Plan \\
\hline & & & Monitoring Evaluation \\
\hline & & ICT & Innovation \\
\hline & & & Data Center \\
\hline & & & Integration \\
\hline & & Human Resource & Staffing \\
\hline & & & Skill \\
\hline & & & Training \\
\hline \multirow[t]{8}{*}{ MIS } & ICT & Software & SSO \\
\hline & & & LMS \\
\hline & & & KMS \\
\hline & & & PMS \\
\hline & & Hardware & Network \\
\hline & & & Server \\
\hline & & & Bandwidth Capacity \\
\hline & & & Security \\
\hline
\end{tabular}

They are using those research indicators, observing, interviewing, and discussing with stakeholders (teachers, students, technical staff) in SMAN 34 Jakarta in OctoberDecember 2018. This Community service program conducted. With this model of research, we can recommend to the school how they need to act to achieve a proper ELearning method in their learning activity.

\section{Methods}

This research was conducted using descriptive qualitative methods and analyzed using triangulate analysis, using a professional perspective, an expert in E-Learning, focus group discussion, and observation result (N. K., Denzin \& Lincoln, 2005; Creswell, 2018). The observation and community service activity conducted from October-December 2018. The scope for this activity for socialization and workshop how to use basic level of 
E-Learning for teachers and students; for IT Staff that manage LMS in this school, we did some advice and helped how to create a proper LMS website. Limitation for this activity mainly about time management and resource management that can be done when this activity conducted.

\begin{tabular}{|c|c|c|c|c|}
\hline Stakeholders & Group & Direct Action & Internal & External \\
\hline$\overline{\text { Students }}$ & Customers & $\sqrt{ }$ & & $\sqrt{ }$ \\
\hline Employers & Customers & $\sqrt{ }$ & & $\sqrt{ }$ \\
\hline Educational Institutions & Suppliers & $\sqrt{ }$ & $\sqrt{ }$ & $\sqrt{ }$ \\
\hline Accreditation Bodies & Suppliers & $\sqrt{ }$ & & $\sqrt{ }$ \\
\hline Teachers & Suppliers & $\sqrt{ }$ & $\sqrt{ }$ & $\sqrt{ }$ \\
\hline Content Providers & Suppliers & $\sqrt{ }$ & $\sqrt{ }$ & $\sqrt{ }$ \\
\hline Education Ministry & Board and Shareholders & $\sqrt{ }$ & & $\sqrt{ }$ \\
\hline Teachers' Association & Professional Associations & $\sqrt{ }$ & & $\sqrt{ }$ \\
\hline Students' Commissions & Special Interest Groups & $\sqrt{ }$ & & $\sqrt{ }$ \\
\hline Technology Providers & Suppliers & $\sqrt{ }$ & & $\sqrt{ }$ \\
\hline
\end{tabular}

Fg. 7 E-Learning Stakeholder

Source: E-Learning Stakeholder Concept (Aparicio et al., 2016)

Based on E-Learning Stakeholder concept above, here are the list of interviewees that involved. Mainly the main actors that can make an E-Learning success (Aparicio et al., 2016). The headmaster of SMAN 34 Jakarta, Fatma Erlinda, as an interviewee for the readiness of school in using E-Learning. The head of the academic division and a teacher, Juli Sugianti, as an interviewee for the preparedness of curriculum in using E-Learning. The Technical staff of SMAN 34 Jakarta, Hari, as an interviewee for the readiness of infrastructure or IT support in using E-Learning.

For participant involvement in this community service program, mainly teachers and students. For a teacher, at least 25 teachers involved in this community service program; divided into three categories: 1) Social Science Teachers, 2) Natural Science Teachers, and 3) General Science Teachers. For a student, at least eight students involved in this community service program; all the students from grade 10.

This community service program runs on a set of timelines. From preparing a program proposal, communicating with the school, first activity, other activity, third activity, and monitoring activity. All of that can be seen in the table below. 
Fikri Anza, Achmad Luthfi, Arfah Saragih| ASEAN Journal of Community Engagement | Volume 3, Number 1, 2019

Table 2. Community Service's Timelines

\begin{tabular}{|c|c|c|}
\hline Date & Location & Agenda \\
\hline Mar 23rd 2018 & SMAN 34 Jakarta & Give proposal to Academic Division \\
\hline Mar 30th 2018 & SMAN 34 Jakarta & $\begin{array}{l}\text { Provide an early program introduction to } \\
\text { Headmaster SMAN } 34 \text { Jakarta }\end{array}$ \\
\hline Aug 31st 2018 & SMAN 34 Jakarta & $\begin{array}{l}\text { FGD and Timetable confirmation for community } \\
\text { service program }\end{array}$ \\
\hline Sept $28^{\text {th }} 2018$ & SMAN 34 Jakarta & $\begin{array}{l}\text { Observing and Configuring LMS for E-Learning } \\
\text { activity }\end{array}$ \\
\hline Oct $5^{\text {th }} 2018$ & SMAN 34 Jakarta & First activity, introduction E-Learning \\
\hline Oct $12^{\text {th }} 2018$ & SMAN 34 Jakarta & Second activity, online class management \\
\hline Nov $2^{\text {nd }} 2018$ & SMAN 34 Jakarta & Third activity, quiz management \\
\hline Dec 2018 & SMAN 34 Jakarta & $\begin{array}{l}\text { Observing and Monitoring activity for a month } \\
\text { (once a week) }\end{array}$ \\
\hline
\end{tabular}

Source: Authors (2018)

\section{Result and Discussion}

\subsection{Leadership}

\subsubsection{Policy (Governance and ICT)}

On the policy side, the policy used by the school in implementing E-Learning is still a direct policy from the Regulation of the Minister of Education and Culture Number 3 of 2017 for learning evaluation procedure (Kemendikbud, 2017). Besides that, (Sugianti, 2018) said that the policy they still use is the Regulation of the Minister of Education and Culture Number 114 of 2014 for using LMS as a Computer Based Test (CBT/UNBK) media (Kemendikbud, 2014). While the policy of the school itself is only in the form of verbal policies from the Principal (Hari, 2018). This fact will be a problem in the future because there is no internal policy that said formally how to regulate evaluation procedures based on computers, the process to develop E-Learning environment, assignment and responsibility staff regarding E-Learning, plan in budgeting for E-Learning, expect in developing E-Learning, and so on. If this condition continues, there will be potential resistance to the next leader, and implementing E-Learning will fail in the future. 
To maintain the quality of electronic-based learning, making an E-Learning management team is very necessary. Therefore, strengthening the E-Learning management team needs to be formally written in the form of a Principal Decree, which had previously been derived from the Policy that regulates SMAN 34 Jakarta School ELearning.

From the results of observations in the field, it was found that the E-Learning team doesn't exist, only one staff member who held all E-Learning activities at school. "The only one who manages E-Learning and the ICT section of the school is only me," said Hari ICT staff of SMAN 34 Jakarta (Hari, 2018).

The main tasks and functions, the E-Learning management team also needs to be explained with certainty, starting from planning, directing, managing, monitoring and evaluating E-Learning activities in the school. With the existence of the team, knowledge in leading E-Learning is not just one person. So that if the person is affected by the problem, E-Learning activities can still run safely.

IT Masterplan in the development of E-Learning is also needed. With this document, it can help ICT budgeting, and IT Staffing required in the future.

"..... I only run what the Principal has ordered, I cannot give too much input for the development of E-Learning ......" said Hari.

Again, we get information that at SMAN34 Jakarta does not have careful planning or proper sustainable ICT budgeting. It also shows that the leadership role, in this case, the Principal, has a vital role in directing the success of the E-Learning program in the future. Integrity and ethical leadership commitment are needed so that the E-Learning program can continue.

For the main tasks and functions, the E-Learning management team also needs to be explained with certainty, starting from planning, directing, managing, monitoring, and evaluating E-Learning activities in the school. Those tasks must be detailed in the policy, and all school management must agree with this.

Besides that, the internal ICT Policy, namely Innovation, Data Center, and Integration, must be created in the future. Thus, every stakeholder in SMAN 34 Jakarta can contribute more, in developing E-Learning SMAN 34 Jakarta better. For Data Center and Data Integration, the first step they must do is to build the proper Data Center or just rent Data Center with the vendor in Jakarta. We saw the condition of the server room is alarming, 
and there is no adequate air conditioning, no fire extinguisher, no backup server, and much more. For Integration, we also found some depression information; there is no such thing as integration planning, as small as like Single Sign-On (SSO) for E-Learning user; therefore, ICT management staff must carry out routine manual activities continuously, such as user registration to E-Learning classes, update new passwords, etc.

Thus, in policy at ICT aspect, we can see innovation only appear from the central government (Kemendikbud). There is no room for innovation internally because the leader's commitment didn't saw change would be suitable for their school. They defended this because of a problem in lacking ICT development's budget, especially in E-Learning (Erlinda, 2018) which makes them refuse to create innovation though this can be solved if they had a good IT Masterplan.

\subsection{E-Learning}

\subsubsection{Governance (Institutional, Plan-Strategy, ICT, HR)}

For management, in the institutional aspect, plan and strategy aspect, ICT, and HR aspect; overall, all these aspects are still problematic. This problem happens because generally, good governance can only be adequately implemented if it can be derived from existing policies. Because internal systems yet don't exist, all aspects of E-Learning management are far from good, even none.

For instance, in the institutional aspect, the team E-Learning didn't exist. Only one man did everything related to E-Learning. There is no teacher that has competency in ITrelated subject. For E-Learning procedure itself, everything based on regulation from central, not also once they had any formal process for E-Learning. Even for CBT (UNBK), they only did what the center said if they had a system problem; they must wait for instruction from central to repair CBT system.

Furthermore, for the procedure section, the overall aspect is not fulfilled. Whether it's aspects of data integration procedures or evaluation procedures to maintain quality. From the observations, one ICT staff is not enough to handle entire E-Learning activities at SMAN 34 Jakarta.

"...... I was asked by the teachers to upload exam questions, I was also asked to check the results of the statistical reports for each test ......" said Hari (Hari, 2018). 
From the statement, aside from being overloaded with assignments, it was seen that there was also a lack of division of essential tasks from the academic division to evaluate exam questions to maintain their quality.

For plan and strategy aspect, they don't have any project related to E-Learning. They don't know where they will head in the future. And if the central order them to implement a full E-Learning concept in their learning environment, they will be overwhelmed to adjust it because they don't have any plan for proper staffing, good infrastructure, good academic curriculum, and anything related to E-Learning development. And like before, they will say, lack of budget will be their excused (Erlinda, 2018). Still, this problem will be solved if only they had a proper E-Learning Masterplan, IT Budget Plan, and Monitoring-Evaluation Plan.

For ICT aspect, they don't have any innovation regarding endorsement in using information technology for education. They excused, some of the teachers will be retiring, still study for a master's degree, didn't have time, out of responsibility as a teacher, and other reasons. Nevertheless, here, everything can be solved using policy by providing a reward and punishment policy scheme. So, the principal's commitment is tested here related to the development of E-Learning. However, innovation in ICT must go according to the vision and mission of the school. Here is seen the role of a kind master plan is needed. So that continuous developments related to integration, data centers, human resource competencies, training, and others can be adequately accommodated.

For the human resource section, the school needs to train or recruit more employees who have enough ability and competency to carry out E-Learning activities. Even if they don't want to hire well-qualified employees, the school must conduct regular training for other teachers, so they become better in using E-Learning next time (not drop all things related to E-Learning to one staff member). 


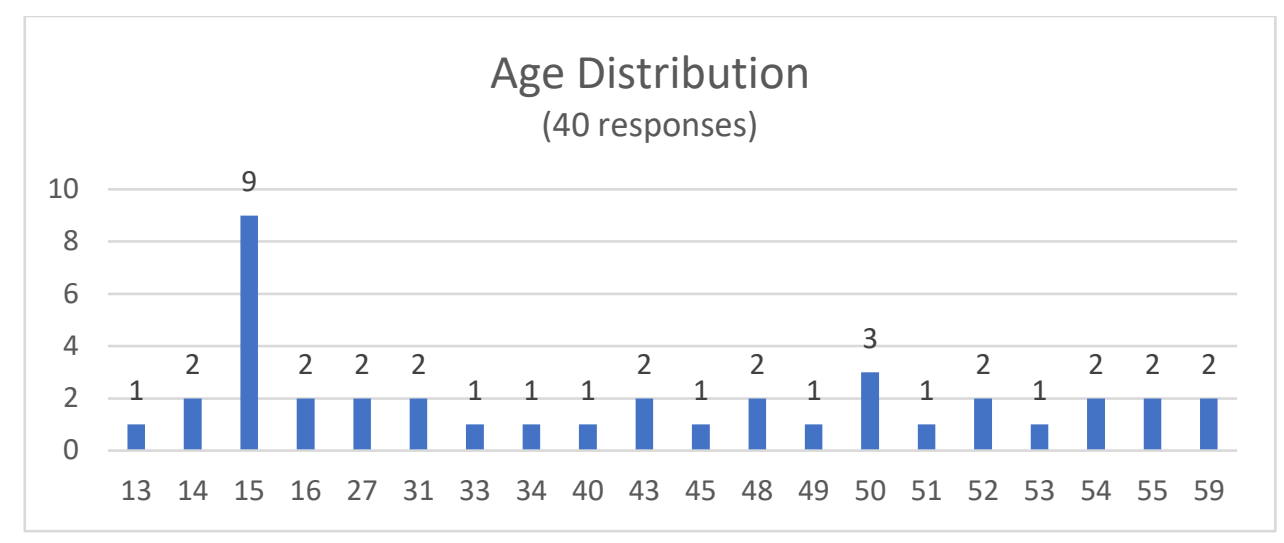

Fg. 8 Age Distribution

Source: Authors (2018)

For the observation result about human resources, we can say that almost $70 \%$ of teachers that participated in socialization and workshop this activity was a senior citizen that still not aware or not an IT savvy person. This can be seen from fig. 9 below, which said only $22.5 \%$ participants that confident they good using IT - this fact generated from the result in the Google Form Survey that we distributed.



Fg. 9 ICT Savviness

Source: Authors (2018)

This fact can be seen when we did this community service activity. When the workshop conducted, many participants didn't know how to log in, and even they don't know their username-password when using LMS. Only IT teacher, Academic staff, and ICT Staff that 
understand how to use LMS properly. Additional information, we can saw the last activity for using LMS for their last login in LMS, Figure 10 below.

\begin{tabular}{|c|c|c|c|}
\hline Email address & City/town & Country & Laytaccess \\
\hline admin@desainbangun.com & Jakarta & Indonesia & $1 \mathrm{sec}$ \\
\hline 17373@sman34jkt.sch.id & Jakarta & Indonesia & days 16 ho \\
\hline 17415@sman34jkt.sch.id & Jakarta & Indonesia & \\
\hline 17544@sman34jkt.sch.id & Jakarta & Indonesia & 94 days 1 hour \\
\hline
\end{tabular}

Fg. 10 Last Activity using LMS

Source: Authors (2018)

From Figure 10, we can saw only they only access LMS when this activity conducted from October-December 2018. After that, they don't use it anymore. Even students, Academic staffs, and Teachers; they don't access LMS for the past 30 days.

\subsection{Management Information System}

\subsubsection{ICT (Software, Hardware)}

For the ICT section, only one aspect is fulfilled in the software aspect, namely the implementation of Learning Management System (LMS), E-Learning of SMAN 34 Jakarta; while other elements are not fulfilled at all. For example, the Single Sign-On aspect, if this can be implemented, the routine activities of E-Learning management staff in entering user data into LMS will be resolved; SSO can even be used to other systems in the school, such as the staffing system, financial system, school internet system, academic system, etc.

In the aspect of Knowledge Management System (KMS), because E-Learning has not been used optimally, the knowledge repository of teachers, students, and staff in the school has not been collected so that it will be difficult regarding future knowledge sharing. The advice we can give is the simple implementation of the Mediawiki.

In the aspect of Project Management System (PMS), like the previous aspects, PMS has not been implemented at all. We hope that the school will immediately fulfill knowledgebased PMS; so, there is no need to implement KMS. This PMS is beneficial for monitoring various types of activities/projects in schools so that if the management staff changes, the knowledge of the project will remain in the school. 
In the aspect of ICT related to hardware, we found various kinds of obstacles, such as internet network management, which was still not right, E-Learning which was still offline (access by LAN only), and system security issues that were always questionable.

For E-Learning problems that are still offline. The existence of E-Learning that has been online existed but is constrained in the server hosting bandwidth problem. Thus, if the online E-Learning is accessed simultaneously by approximately 30 users, accessing E-Learning will be slow.

"...... We have opened an E-Learning online, at http://E-Learning.sma34jkt.sch.id, but when used together with approximately 30 users, the web is inaccessible. Probably because bandwidth management problem ......" said Hari.

Seeing this problem, we discussed and provided a solution to buy DNS and rerouting the DNS to a Local-managed Server in SMAN 34 Jakarta. For optimization, we have also considered changing the appearance of E-Learning websites to be more "feasible" to be like an E-Learning website in general. The figure below will show how LMS in SMAN 34 Jakarta look compared to LMS in FIA UI that already had a proper examination of ELearning feels. This is a challenge for SMAN 34 Jakarta to be able to change the way they use E-Learning initially. Together with changing their paradigm related to E-Learning.

For security issues, we see a security threat because it has not been appropriately managed because of E-Learning user data (not yet managed using SSO), so there is still a sharing of username-passwords, social engineering hack, etc. Therefore, we recommend that SMAN 34 Jakarta immediately implementing SSO, and keep dividing the E-Learning system into 2, offline E-Learning (for examinations) and online E-Learning (for distance learning). 


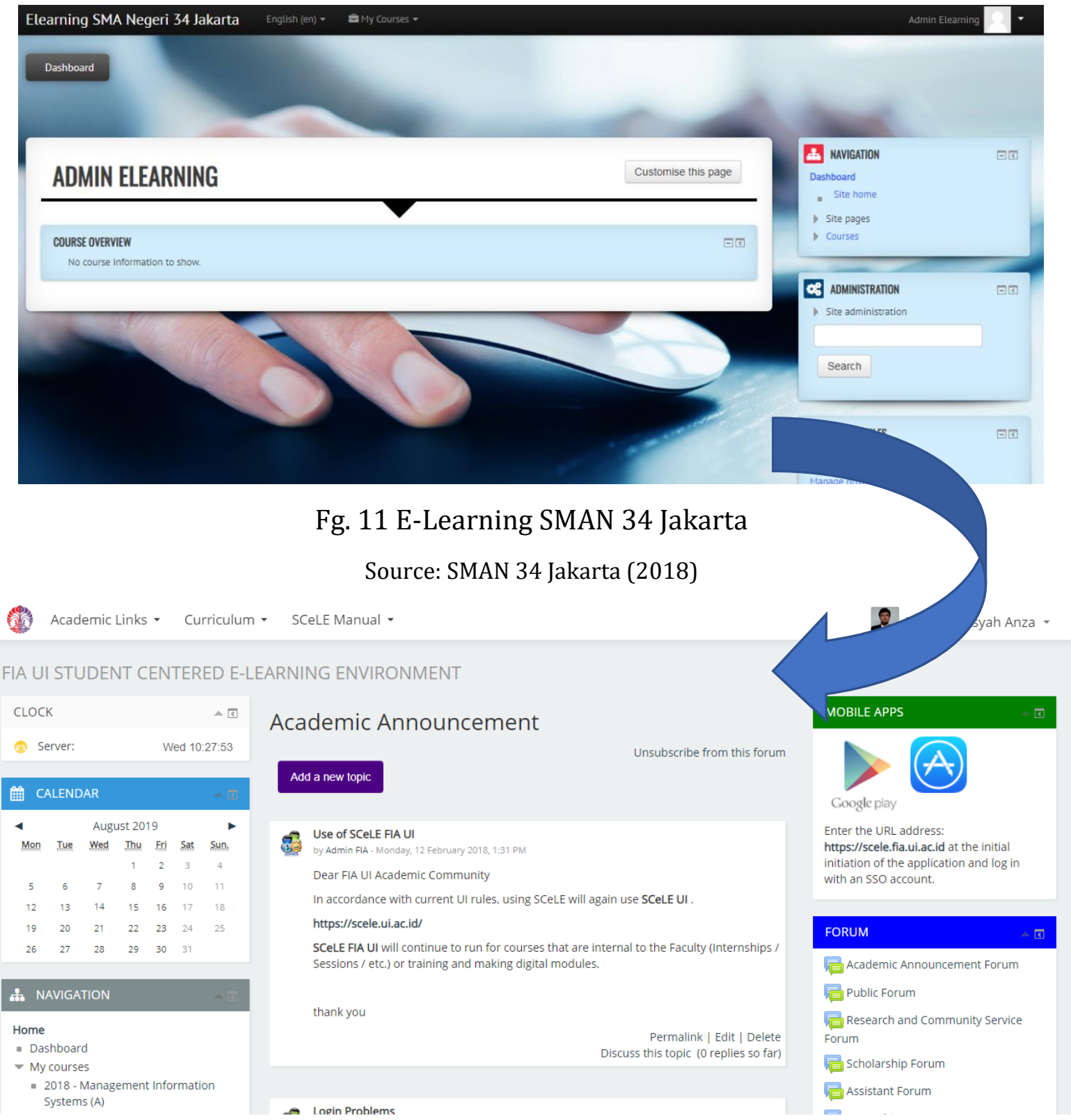

Fg. 12 E-Learning FIA UI

Source: FIA UI (2018)

For the Data Center section, the school has no proper procedures at all about the creation, management, security, operation, and allocation of personnel for the Data Center. Even if they do not have the cost of building a standardized Data Center space in general, they can have other options for renting Data Centers with outside parties; so, they can focus on their primary task. 


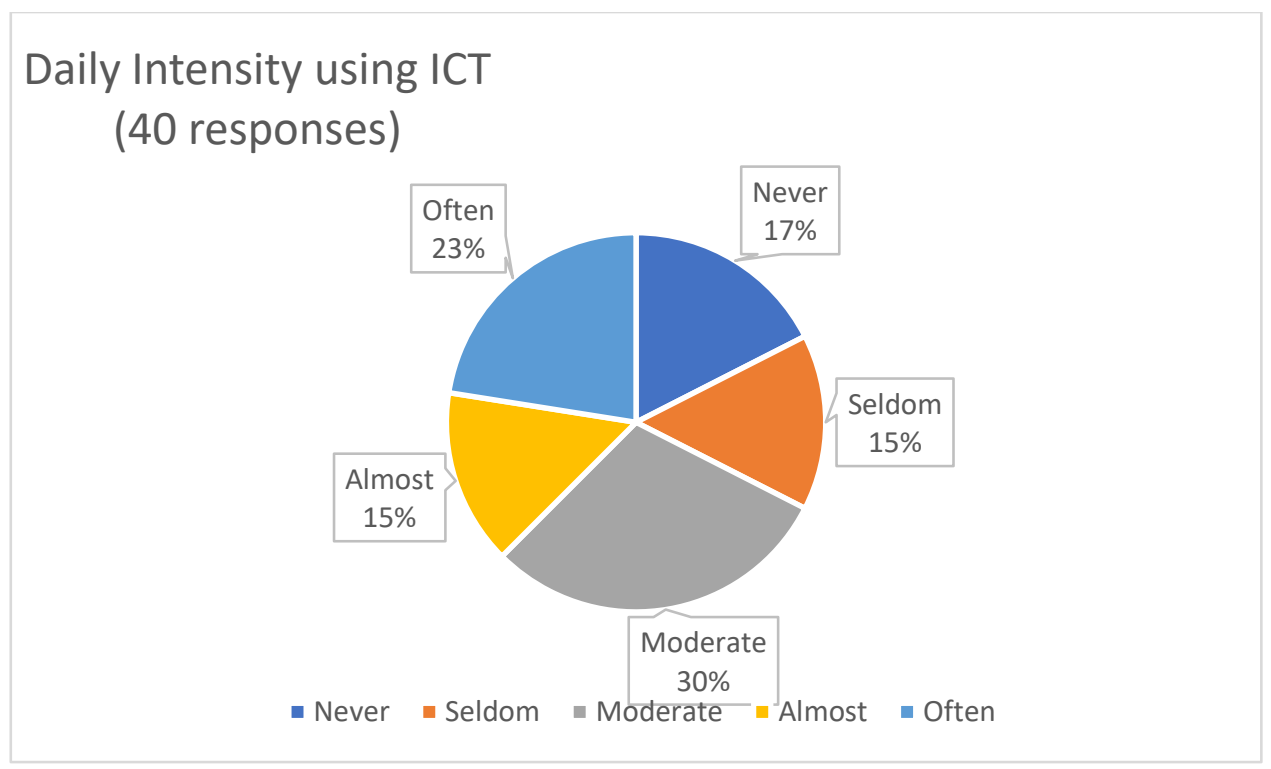

Fg. 13 ICT use intensity

Source: Authors (2018)

This fact can be seen by "IT use intensity" that we distributed in google form beforehand. It said that only $37.5 \%$ of participants that confident they use IT in every aspect of their life. We conclude that there is no urgency in creating data center because not all participant needed IT that produce digital data in their life, especially for Learning purpose in school. This fact confirmed by Hari ICT Staff in school that said, "Why we need datacenter? Almost all staff in school and students didn't do online activities in school network in here only LAN and offline for study purposes. Regulation in school also said that they forbid 'online activity' when they study in school".

Here is the community service activity that already held in 2018. Even if SMAN 34 Jakarta is one of the best schools in Jakarta, awareness regarding E-Learning still low. Referring to that, we think many senior high schools in Jakarta, probably have a worse condition related to E-Learning development. And this concern must be addressed, at least from the top (central) level to the bottom level (top-down approach).

\section{Conclusion}

The results showed that there were still many teachers who were not aware of the importance of LMS so that the participation of teachers and students even used traditional methods. The student's commitment has what commitment their teacher will give if the teachers have not been committed to using LMS optimally, so will their 
students. LMS technical staffs themselves also face similar problems, where the direction of professional teams implementing LMS depends on the course of the leader.

Empowerment in Policy, Governance, ICT, Procedure, HR, and Data Management is a must. They need a proper IT Masterplan to reform IT Budget Plan and MonitoringEvaluation plan, to address the continues improvement in E-Learning because everything can be appropriately executed if they already had a proper program to fulfill their vision and mission.

For managing HR in developing LMS, it can be done using the Project Management System (PMS), so they can track every activity precisely until the detail problems and solutions. Our suggestions, besides developing LMS to a proper LMS like SCeLE Universitas Indonesia, they can use a knowledge-based PMS like Phabricator. The leader has a significant role in this development, and they need commitment and integrity from their leader to make E-Learning run well.

\section{Acknowledgements}

For this community service program, we would like to give appreciation to Universitas Indonesia, for giving grants in this research, especially DRPM UI. For Administrative Science Faculty UI, Public Administration Department that already permitted us, to conduct this research outside Universitas Indonesia. For SMAN 34 Jakarta that already gave us a warm welcome with an open hand and gave us data and photos for using in this article. And the last one, Community Service's Team, that support this event from the beginning until the end.

\section{References}

Al-Adwan, A., \& Smedley, J. (2013). Exploring students acceptance of e-learning using Technology Acceptance Model in Jordanian universities Amer Al-Adwan Applied Science University, Jordan. International Journal of Education and Development Using Information and Communication Technology, 9(2), 4-18. Retrieved from http://ijedict.dec.uwi.edu/include/getdoc.php?id=5522\&article=1617\&mode=pdf Aparicio, M., Bacao, F., \& Oliveira, T. (2016). An e-Learning Theoretical Framework An eLearning Theoretical Framework. Journal of Educational Technology \& Society, 19(January), 292-307. 
Fikri Anza, Achmad Luthfi, Arfah Saragih| ASEAN Journal of Community Engagement | Volume 3, Number 1, 2019

Clark, R. C. (2016). E-Learning and the Science of Instruction: Proven Guidelines for Consumers and Designers of Multimedia Learning. New Jersey: John Wiley \& Sons Publisher.

Clover, I. (2017). Advantages and Disadvantages of E-Learning Technique. Retrieved January 1, 2019, from Advantages and Disadvantages of E-Learning website: https://elearningindustry.com/advantages-and-disadvantages-of-elearning

Creswell, J. W. (2018). Research Design: Qualitative, Quantitative, and Mixed Methods Approaches. Washington DC: Sage Publisher.

Davis, G. B. (2006). Management Information System. New York: McGraw-Hill.

Dunleavy, P. (2006). Digital Era Governance: IT Corporations, the State, and eGovernment 1st Edition. In Whose Peace? Local Ownership and United Nations Peacekeeping (1st ed.). https://doi.org/10.1093/acprof

Erlinda, F. (2018). Kesiapan Sekolah SMAN 34 Jakarta dalam Penggunaan E-Learning.

Goodwin, D. K. (2018). Leadership: In Turbulent Times. New York: Simon \& Schuster.

Hari. (2018). Kesiapan Infrastruktur dalam Penggunaan E-Learning SMAN 34 Jakarta.

Hassanzadeh, A., Kanaani, F., \& Elahi, S. (2012). A model for measuring e-learning systems success in universities. Expert Systems with Applications, 39(12), 10959-10966. https://doi.org/10.1016/j.eswa.2012.03.028

Keegan, D. (1988). On defining distance education. In Distance Education: International Perspectives. London: Routledge.

Kemendikbud. (2013). Permendikbud RI Nomor 109 Tahun 2013. Retrieved from https://www.unm.ac.id/files/surat/permen_tahun2013_nomor109.pdf

Kemendikbud. (2014). Permendikbud RI Nomor 114 Tahun 2014. Retrieved from https://luk.staff.ugm.ac.id/atur/Permendikbud144-2014UjianNasional.pdf

Kemendikbud. (2017). Permendikbud RI Nomor 3 Tahun 2017. Retrieved from http://simpuh.kemenag.go.id/regulasi/permendikbud_03_17.pdf

Loh, C., Wong, D., Quazi, A., Russel, P., \& K. (2016). Re-examining students' perception of e-learning: an Australian perspective. International Journal of Educational Management, 30(1).

Maxwell, J. C. (2013). The 5 Levels of Leadership: Proven Steps to Maximize Your Potential. New York: Center Street.

Moodle. (2017). Moodle Docs. Retrieved March 12, 2018, from 
https://docs.moodle.org/34/en/Main_page

N. K., Denzin \& Lincoln, Y. S. (2005). The SAGE Handbook of Qualitative Research, Third Edition (3rd ed.). Washington DC: SAGE Publisher.

Najmul Islam, A. K. M. (2011). Students' e-learning system usage outcomes: A study with a learning management system. IFIP Advances in Information and Communication Technology, 353, 255-268.

Nuechterlein, J. E. (2013). Digital Crossroads: Telecommunications Law and Policy in the Internet Age second Edition. Massachusetts: The MIT Press.

Ordonez, K. (2018). Association 4.0 - Positioning for Success in an Era of Disruption. Oregon: Luminare Press.

Paulsen, M. F. (1998). Online Education : Pedagogical, Administrative, and Technological Opportunities and Limitations. (October). Retrieved from http://www.ufrgs.br/niee/eventos/RIBIE/1998/pdf/conferencias/003_MORTEN. pdf

Power, M. (2008). The Emergence of a Blended Online Learning Environment. Journal of Online Learning and Teaching, 4(4), 503-514. Retrieved from http://anitacrawley.net/Resources/Articles/Power2008.pdf

Salmon, G. (2013). Etivities: The Key to Active Online Learning. London: Sterling.

Stoker, S. (2016). an Overview of the Global eLearning Market by Area. Retrieved March 12, 2018, from https://elearningbrothers.com/blog/overview-global-elearningmarket-area/

Sugianti, J. (2018). Kesiapan Bagian Kurikulum dalam Penggunaan E-Learning SMAN 34 Jakarta.

Sun, P., Tsai, R. J., Finger, G., \& Chen, Y. (2008). What drives a successful e-Learning ? An empirical investigation of the critical factors influencing learner satisfaction. $\begin{array}{llll}\text { Computers } \quad \& \quad \text { Education, } & 50,\end{array}$ https://doi.org/10.1016/j.compedu.2006.11.007

Susanti, A. (2015). Banyak Kampus Melirik Metode E-Learning. Retrieved March 12, 2018, from https://news.okezone.com/read/2015/08/17/65/1197547/banyakkampus-melirik-metode-e-learning 